\title{
ULTRAVIOLET LIGHT INDUCED ALTERATION TO THE SKIN
}

\author{
Alena Svobodova*, Daniela Walterova, Jitka Vostalova \\ Institute of Medical Chemistry and Biochemistry, Faculty of Medicine, Palacký University, Hněvotínská 3, 77515 Olomouc, \\ Czech Republic; \\ e-mail:alf.svoboda@seznam.cz
}

Received: April 28, 2006; Accepted: May 15, 2006

Key words: UV radiation/Skin/DNA damage/Reactive oxygen species (ROS)/p53/Antioxidant enzymes

Solar light is the primary source of UV radiation for all living systems. UV photons can mediate damage through two different mechanisms, either by direct absorption of UV via cellular chromophores, resulting in excited states formation and subsequent chemical reaction, or by phosensitization mechanisms, where the UV light is absorbed by endogenous (or exogenous) sensitizers that are excited and their further reactions lead to formation of reactive oxygen species (ROS). These highly reactive species can interact with cellular macromolecules such as DNA, proteins, fatty acids and saccharides causing oxidative damage. Direct and indirect injuries result in a number of harmful effects such as disrupted cell metabolism, morphological and ultrastructural changes, attack on the regulation pathways and, alterations in the differentiation, proliferation and apoptosis of skin cells. Processes like these can lead to erythema, sunburn, inflammation, immunosuppression, photoaging, gene mutation, and development of cutaneous malignancies. The endogenous and exogenous mechanisms of skin photoprotection are discussed.

\section{INTRODUCTION}

Ultraviolet (UV) radiation has a few beneficial health effects like vitamin $\mathrm{D}_{3}$ formation or application in combination with drugs in the therapy of skin diseases including psoriasis and vitiligo, but it also causes many acute and chronic detrimental cutaneous effects, which may result in development of skin malignancies. Among all human cancers, skin cancer is currently one of the most common types. The incidence of both melanoma and non-melanoma skin cancers (basal cell carcinoma (BCC) and squamous cell carcinoma (SCC)), the serious consequence of UV action, is still increasing worldwide ${ }^{1}$.

Sunlight is composed of a continuous spectrum of electromagnetic radiation that is divided into three main parts of wavelengths: ultraviolet (45\%), visible (5\%), and infrared (50\%). UV light region occurs between $100-400 \mathrm{~nm}$ (Fig. 1). According to the International Commission on Illumination, UV radiation is divided into three categories depending on the wavelength: long wave UVA (315-400 nm), medium wave UVB (280-315 nm), and short wave UVC (100-280 nm $)^{2-4}$. The ozone layer efficiently absorbs UV radiation up to about $310 \mathrm{~nm}$ thus it consumes all UVC and most of UVB (95\%). However, UVA is not absorbed at all ${ }^{5}$. Due to substantial damage to the protective ozone layer an increased amount of UVB radiation is reaching the ground ${ }^{4}$.

UVA comprises more than $95 \%$ of solar radiation that reaches us. Compared to UVB, this long wave radiation penetrates deep into the epidermis and dermis of the skin and is about 1000 times more effective in the production of an immediate tanning effect, which is caused by darkening of the melanin in the epidermis ${ }^{3}$. Intense or extensive exposure to UVA can burn sensitive skin, and if prolonged, it can damage underlying structures in the corium and cause premature photoaging of the skin. More or less early signs of photoaging include wrinkling, wilting, laxity, sagging, patchy pigmentation, dryness etc. UVA injury

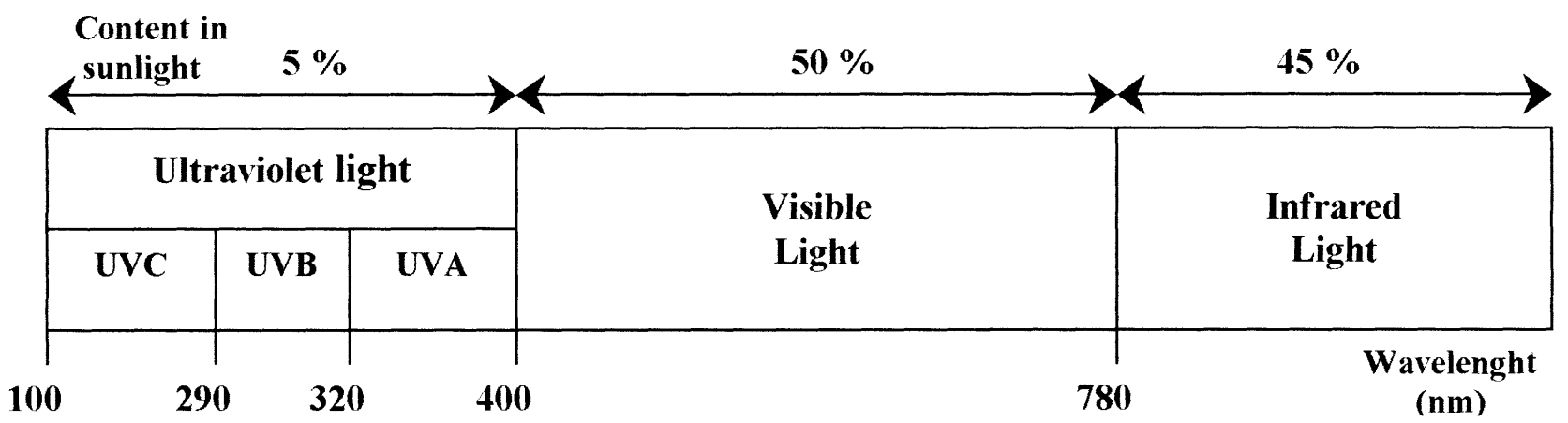

Fig. 1. Solar radiation spectrum. 
also causes necrosis of endothelial cells, thus damaging the dermal blood vessels. UVA-induced responses in cells happen mainly indirectly via oxidative processes initiated by endogenous photosensitization. After UVA exposure, reactive oxygen species (ROS) are generated and can mediat damage to cellular proteins, lipids, and saccharides. UVA can produce structural damage to DNA, impair the immune system, and lead to cancer. It has been linked to $67 \%$ of malignant melanoma ${ }^{3,6-8}$.

UVB radiation is a minor but the most active constituent of solar light. It makes up 4 to $5 \%$ of coming UV light. It is most intense from 11:00 a.m. to 1:00 p.m. all year long. It is more genotoxic and about 1000 times more capable of causing sunburn than UVA. UVB is less penetrating and acts mainly in the epidermal basal cell layer of the skin. It induces particularly, direct damage to DNA (the formation of cyclobutane-pyrimidine dimers (CDPs) and pyrimidine-pyrimidone (6-4) photoproducts ((6-4)-PP)) and proteins (interaction with aromatic amino acids). UVB also participates in indirect damage to macromolecules. It provokes free radical production and induces a significant decrease in skin antioxidants, impairing the skin's ability to protect itself against the free radicals generated after sunlight exposure. Furthermore, UVB causes photoisomerization of trans- to cis-urocanic acid (UCA), induction of ornithine decarboxylase (ODC) activity and cell cycle arrest, or impairment of DNA synthesis in the skin. Both direct and indirect adverse biological effects of UVB may result in photoaging and photocarcinogenesis. UVB is considered to be responsible for inducing BCC and SCC due to DNA damage. It is also suspected of lowering the skin's immune defence system ${ }^{6-11}$.

The UVC light is the most energetic and has the greatest potential for biological damage to all forms of life, even with only very short exposures. It is highly mutagenic and toxic. It is absorbed by proteins and nucleic acids and is extremely damaging to the skin. Fortunately, UVC radiation from the sun is completely absorbed in the earth's atmosphere. In the stratosphere the UVC energy is utilized to form ozone from the molecular oxygen and no solar radiation of wavelengths below $280 \mathrm{~nm}$ reaches the surface of the earth ${ }^{2,6,7,12}$.

UV-induced skin injury depends on many variables including wavelength, dose, race, and characteristics of the skin tissue ${ }^{13}$. While UVB is maximal between $11 \mathrm{a} \mathrm{m}$.1 p. m., UVA still makes up to $50-60 \%$ of the phototoxic wavelength, and this is increased at other times ${ }^{3}$. Obtainable UV dose increases with an increasing altitude and decreasing latitude and also changes with the season (Tab. 1). Most indoor-working adult Europeans get 10$20 \mathrm{~kJ} . \mathrm{m}^{-2}$ per year, Americans $20-30 \mathrm{~kJ} . \mathrm{m}^{-2}$ per year and Australians $20-50 \mathrm{~kJ} . \mathrm{m}^{-2}$ per year. Holidays can increase the dose by $30 \%$ or more. Outdoor-working people get about 2.5-5 times higher UV dose than indoor-working ones that represent $10 \%$ of the total available annual UV amount ${ }^{14}$. Individual genetic sensitivity is also an important determinant of the susceptibility to UV radiation ${ }^{13}$.
Table 1. Solar irradiance measurement during the seasons (taken form $\mathrm{ref}^{14}$ ).

\begin{tabular}{lcccc}
\cline { 2 - 5 } & \multicolumn{4}{c}{ Solar noon measurements } \\
\cline { 2 - 5 } & $\begin{array}{c}\text { Spring } \\
3 / 27\end{array}$ & $\begin{array}{c}\text { Summer } \\
6 / 30\end{array}$ & $\begin{array}{c}\text { Autumn } \\
9 / 27\end{array}$ & $\begin{array}{c}\text { Winter } \\
12 / 20\end{array}$ \\
\hline UVB $\left(\mathbf{m W} / \mathbf{c m}^{2}\right)$ & 0.211 & 0.243 & 0.211 & 0.060 \\
UVA $\left(\mathbf{m W} / \mathbf{c m}^{2}\right)$ & 4.20 & 4.20 & 3.90 & 1.78 \\
Ratio UVA/UVB & 19.9 & 17.3 & 18.5 & 29.7 \\
\hline & \multicolumn{4}{c}{ Integral daily dose } \\
\hline UVB $\left(\mathbf{J} / \mathbf{c m}^{2}\right)$ & 4.26 & 6.19 & 4.51 & 1.19 \\
UVA (J/cm $)$ & 99.4 & 127.8 & 97.9 & 40.3 \\
Ratio UVA/UVB & 23.3 & 20.6 & 21.7 & 35.1 \\
\hline
\end{tabular}

\section{MECHANISMS OF UV-INDUCED BIOLOGICAL DAMAGE}

To exert its biological effects, UV light energetic photons must be first transmitted through skin layers and absorbed by a cellular molecule (chromophore, photosensitizer). Then series of biological reactions are initiated. UV radiation induces damage via two different mechanisms. One is direct absorption of UV photons by cellular chromophores that can lead to photo-induced reactions. This kind of injury is typical for DNA bases. The second, indirect way, include photosensitization processes, where endogenous or exogenous sensitizers absorb UV light ${ }^{10}$. Absorbing the energy of the photons changes the distribution of electrons in the chromophores/photosensitizer molecule and creates the excited singlet state. In this state, the molecule can emit fluorescence, lose the energy as heat, undergo a photochemical reaction to form photoproducts, or change into the triplet excited state. In this long-lived state, the molecule emits phosphorescence, photochemically reacts (Fig. 2), or returns to the ground state $^{10,15}$. Subsequent photobiochemical reactions, depending upon the epidermal thickness, the concentration and the distribution of chromophores, provoke changes in cell and tissue biology ${ }^{3,8}$.

Cellular damage via an excited photosensitizer may occur by two major pathways often called Type I and

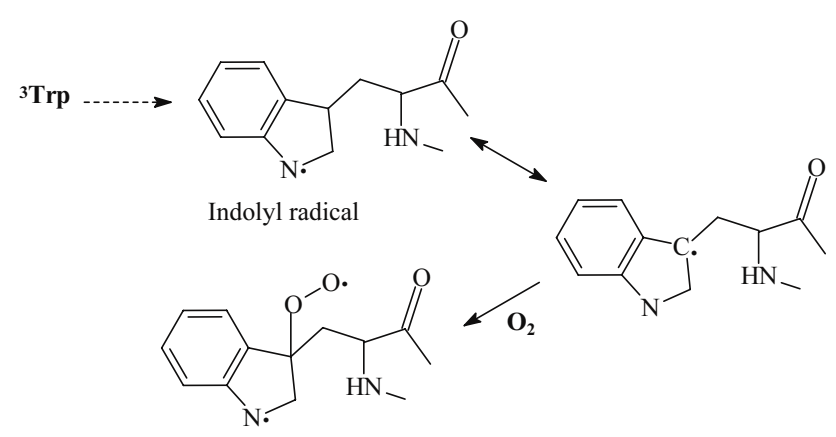

Fig. 2. Reaction of tryptophane in triplet state induced by $\mathrm{UV}$ radiation (taken from ref. ${ }^{10}$ ). 


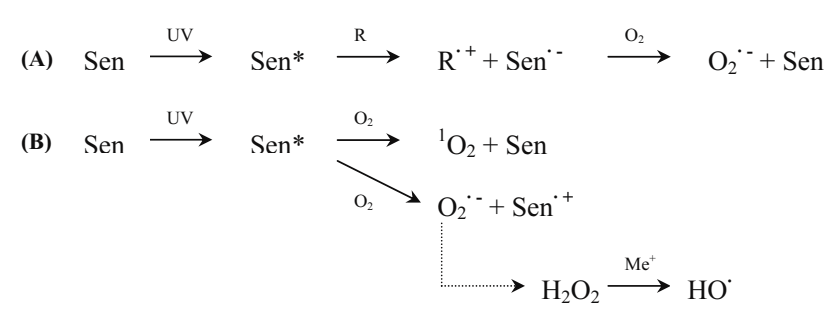

Fig. 3. Mechanisms of indirect UV-induced damage and ROS formation.

Sen - photosensitizer, Sen* - Excited photosensitizer, R - DNA base/aromatic amino acid (protein) $\mathrm{Me}^{+}-$metal cation

Type II. The mechanisms are dependent on the chemical properties of photosenzitizers. Type I mechanisms involve one electron transfer through a direct interaction between an excited photosensitizer and other biomolecules, resulting in free radical formation. This mechanism does not require oxygen for the induction of molecule damage. The Type II mechanism involves energy transfer from an excited sensitizer to molecular oxygen that leads to production of reactive oxygen species (ROS) (Fig. 3). Mostly singlet oxygen, an excited state of oxygen, which is a very powerful oxidant with relatively long lifetime, is generated. However, in minority reactions superoxide anion is also produced, followed by dismutation to hydrogen peroxide ${ }^{10}$. Hydrogen peroxide is not capable of causing damage by itself, but in the presence of metal cations ( Fe, $\mathrm{Cu}$ ) hydroxyl radicals are generated by the Fenton reaction. ROS interactions with cellular biomolecules provoke a final biological response (Fig. 4) (ref. ${ }^{16}$ ).

\section{UV ABSORBING CELLULAR CHROMOPHORES}

Numerous biomolecules in the skin act as radiation absorbents within the UVB range. These are mainly nucleic acids, aromatic amino acids, NADH and NADPH, heme, quinones, flavins, porphyrins, carotenoids, 7-dehydrocholesterol, eumelanin and urocanic acid (UCA) (ref. ${ }^{2,3,8,13,17}$ ). UVA-absorbing cellular molecules in the initiation of UVA-induced photosensitization are still largely unknown, only trans-UCA and melanin have been reported $^{8}$.

The major chromophoric amino acids present in proteins are tryptophane, tyrosine, phenylalanine, histidine, and cysteine. The absorption of UV light by these amino acids can give both excited state species and radicals via photo-oxidation (Fig. 2) $\left(\right.$ ref. $\left.{ }^{10}\right)$.

UCA, a histidine derivative, is a major UV absorbing chromophores in the stratum corneum of human skin. $\mathrm{UV}$ radiation provokes the isomerization of trans-UCA to cis-UCA in a dose-dependent fashion until the stationary state is reached when approximately equal quantities of two isomers are present. The isomerization is maximal be-

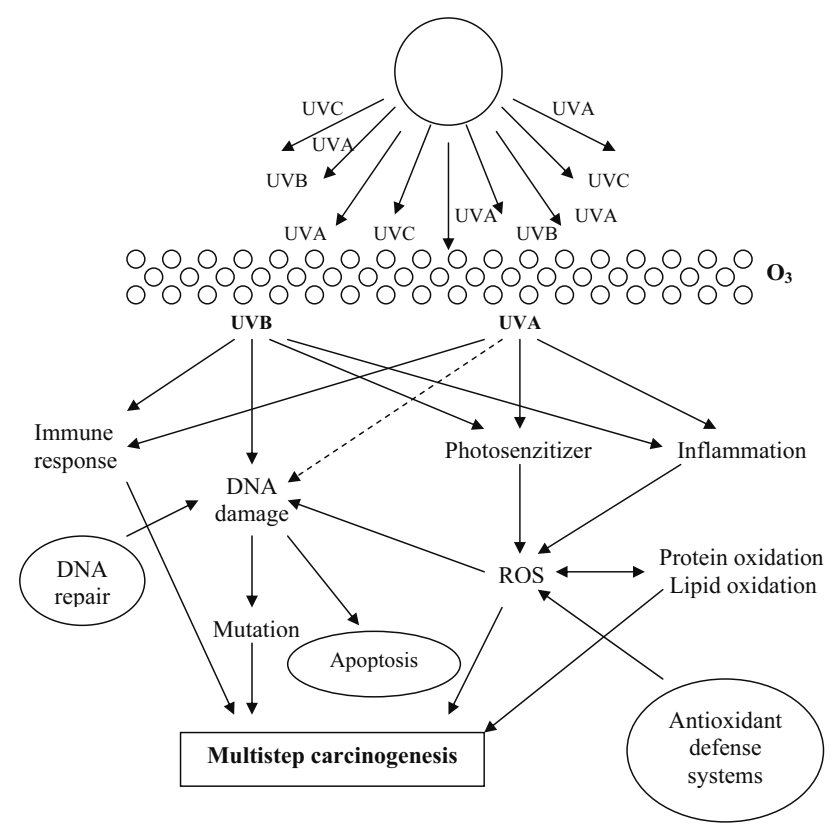

Fig. 4. Action of UV radiation on cellular biomolecules (modified from ref. ${ }^{23}$ ).

tween 300-310 nm in human skin, although wavelengths in the UVA range (315-400 nm) can also induce cis-UCA formation ${ }^{4,18}$.

Melanin acts as a filter by absorbing UVB, UVA, visible and IR radiation, helps transforming this energy into heat, and disperses it between hairs and capillary vessels. It efficiently scavenges $\mathrm{OH}$. and molecular oxygen and preserves the DNA from photoproduct formation. On the other hand, melanin precursors are inherently cytotoxic to the melanocytes. For example, autooxidation of dihydroxyphenylalanine and indolic precursors may give arise to cytotoxic oxygen species. One of these products dihydroxyindol, being similar to the purine bases, can react with DNA by inserting itself between bases and may act as a non-specific mutagen. UV radiation also enhances binding of dihydroxyindol to DNA ( ref. $^{2}$ ).

Other macromolecules such as lipids and polysaccharides do not absorb in the UV region and thus do not undergo direct damage. Their disruption happens mainly via oxidative proceses ${ }^{10}$.

\section{EFFECT OF UV RADIATION ON CELLULAR NUCLEIC ACIDS}

In the skin, nucleic acids are the most critical chromophores for UV radiation-induced biological response in the UVB range. Fortunately, aromatic amino acids of proteins in the stratum corneum, the most peripheral layer of the skin, absorb large amount of UVB before it reaches the nucleic acid molecules in the viable cells ${ }^{2}$. UVB light was experimentally demonstrated to cause DNA damage, mostly by formation of dimeric photoproducts between 
<smiles>[R]n1cc(C)c(=O)[nH]c1=O</smiles><smiles>[R]n1cc(C)c(=O)[nH]c1=O</smiles><smiles>[119In]</smiles><smiles>[R]N1C(=O)NC(=O)C2(C)C3C(=O)NC(=O)C(C)(C3=O)C12[R]</smiles>

cyclobutane-pyrimidine<smiles>[R]n1cc(C)c(=O)[nH]c1=O</smiles><smiles>[R]n1cc(C)c(=O)[nH]c1=O</smiles>

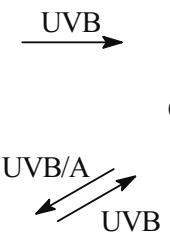<smiles>[R]N1C(=O)NC(=O)C(C)(O)C1c1nc(=O)n([R])cc1C</smiles>

(6-4)-pyrimidine-pyrimidone photoproduct

Fig. 5. Formation of pyrimidine dimer from adjacent pyrimidine bases on the same strand (A), (6-4)-pyrimidinepyrimidone photoproduct and Dewar isomer (B) after absorption of UVB light energy (taken from ref. ${ }^{10}$ ).

adjacent pyrimidine bases on the same strand (Fig. 5), CPDs and (6-4)-PP. Upon exposure to UVB/A light, the (6-4)-PP adducts are readily converted into Dewar valence isomers (Fig. 5). These Dewar isomers are only moderately photoactive, but can undergo reversion to the (6-4)-PPs upon exposure to short-wavelength UV radiation ${ }^{10}$.

Incorrect repair of these lesions leads to mutations in the epidermal cells, which cause the development of cancer cells. Among CPDs, thymine-cytosine (TC) and cytosine-cytosine (CC) dimers are shown to be the most mutagenic, since $\mathrm{TC} \rightarrow \mathrm{TT}$ and $\mathrm{CC} \rightarrow \mathrm{TT}$ mutations are frequently found in the p53 gene of UV-induced cancer cells ${ }^{19}$. (6-4)-PP are repaired more efficiently than CPDs and for this reason CPDs are assumed to be the major contributor to mutations in mammals ${ }^{19,20}$.

One recent study suggests that UVA and UVB radiation induce mutation via similar mechanisms. Differences in the cellular responses to UVA and UVB, such as the less prominent activation of $\mathrm{p} 53$ by UVA, might determine a different mutagenic outcome of UVA- and UVB-induced dimers. The authors speculate that the weaker activation of p53 after UVA exposure, in comparison to the strong activation of p53 after UVB, increases the chance that a pyrimidone dimer leads to mutation formation, due to weaker cell cycle arrest and a subsequent higher chance of damaged template replication, due to less p53-mediated induction of DNA repair. Furthermore, less p53-mediated apoptosis might also increase the chance that cells with damaged DNA or mutations will survive and potentially progress to form skin cancer. If this hypothesis is true, than UVA-induced dimers are more mutagenic due to less pronounced protective DNA damage response ${ }^{21}$.

UV radiation also induces damage to RNA that can lead to structural changes in expressed genes and causes production of un-functional proteins ${ }^{13}$. Furthermore, a blockade of RNA transcription that occurs as a result of DNA photoproduct formation, leads to activation of the p53 protein that induces apoptosis of irradiated keratinocytes $^{3,8}$.

\section{ROS-INDUCED SKIN DAMAGE}

UV exposure to the skin results, among others events, in generation of ROS (Fig. 3). These comprise a number of active metabolites including $\mathrm{OH} \cdot, \mathrm{O}_{2}{ }^{--}$and peroxyl radical and their active precursors namely ${ }^{1} \mathrm{O}_{2}, \mathrm{H}_{2} \mathrm{O}_{2}$ and ozone. Reactive nitrogen species (RNS), such as nitric oxide (NO) and nitric dioxide, are also generated ${ }^{22}$. On the other hand, ROS are natural and inseparable part of metabolism. In skin, they are constantly generated in keratinocytes and fibroblasts, and are rapidly removed by nonenzymic (ascorbic acid, tocopherol, ubiquinol, and glutathione (GSH)) and enzymic antioxidants (catalase (CAT), superoxide dismutase (SOD), thiredoxin reductase, glutathione peroxidase (GPx), and glutathione reduct- 
<smiles>CCN1c2nc(N)[nH]c(=O)c2NC1O</smiles>

8-hy droxy-deoxy guanosine<smiles>[R7]n1cc(O)c(N)nc1=O</smiles>

8-hy droxy-deoxy cy tosine<smiles>[R1]N1c2ncnc(N)c2NC1O</smiles><smiles>[R1]N1C(=O)NC(=O)C(C)(O)C1(O)O</smiles>

thy mine gly col 8-hy droxy-deoxy adenosine

Fig. 6. The major DNA lesions produced by oxidative damage (taken from ref. ${ }^{20}$ ). $\mathrm{dR}$ - deoxyribose

ase) that maintain the pro-oxidant/antioxidant balance, thus resulting in cell and tissue stabilization ${ }^{22,23}$.

However, overflow of ROS, extensively formed by the reaction of UV photons with endogenous photosensitizers in the skin, may overwhelm the antioxidant (AOx) defence mechanisms resulting in pro-oxidant/AOx disequilibrium defined as oxidative stress ${ }^{7,13}$. UVA has a larger impact on oxidative stress in the skin than UVB by inducing ROS/ RNS which damage DNA, proteins and lipids and which also lead to NADH depletion, and therefore energy loss from the cell ${ }^{24}$.

The excess of free radicals results in a cascade of events mediating a progressive deterioration of a cellular structure and function, and this can lead to the differentiation of neoplasic tissues ${ }^{7}$. It has been reported that ROS/RNS induce various types of oxidative DNA lesions that are thought to be important for the initiation stage in carcinogenesis ${ }^{25}$. These highly reactive, short-lived molecules produce single strand breaks, DNA-protein crosslinks, and altered DNA bases. Due to low ionisation potential the guanine bases are the most susceptible to oxidation via both Type I and Type II mechanisms. Adenine is the second, followed by approximately equal reactions for thymine and cytosine. The primary intermediates generated by the Type I reaction are radical cations, which undergo rapid hydration or deprotonation. Hydration of the guanine radical cation produces a reducing radical intermediate. Under reducing conditions this radical is converted to 2,6-diamino-4-hydroxy-5-formamidoguanine, but under oxidizing conditions (e.g. in the presence of molecular oxygen) it is converted to 8-oxo7,8-dihydro-2'-deoxyguanine (8-oxo-dG). Deprotonation of the guanine radical cation leads to series of reactions generating a stable oxazolone product. The primary intermediates of Type II reactions, mediated by singlet oxygen, are endoperoxides generated by cycloadition reaction of the imidazole ring with singlet oxygen. The major decomposition product of these endoperoxides is 8-oxo-dG (ref. ${ }^{10}$ ). Modified bases, particularly 8-oxo-dG, are produced more frequently than single-strand breaks or DNA-protein crosslinks by UVA (ref. ${ }^{1}$ ). 8 -oxo-dG is a characteristic mutagenic lesion (Fig. 6), which generates $\mathrm{GC} \rightarrow \mathrm{TA}$ transversion by pairing with an adenine instead of a cytosine during replication ${ }^{1,26}$.

In addition to nuclear DNA, the DNA in mitochondria may also be altered by UV-induced oxidative stress. As DNA repair is less efficient in mitochondria compared to nuclei, mutations accumulate at a relative rapid rate. Identified mutations are deletions, which can be mediated by UVA-induced ${ }^{1} \mathrm{O}_{2}$. These mutations may alter the cells capacity to carry out oxidative phosphorylation ${ }^{26}$.

ROS also induce damage to cell membranes by peroxidation of fatty acids within the phospholipid structure of the membrane. During this process, lipid peroxide radicals, lipid hydroperoxides and other fragmentation products, that are themselves active oxidizing agents, are formed $^{23}$. The lipid peroxides are comparatively longerlived species and can initiate the chain reactions that enhance oxidative damage ${ }^{16}$. UVA-induced ROS also readily react with membrane lipids and amino acids (Fig. 7). ROS can modify proteins in the tissue to form carbonyl derivatives (Fig. 8).

\section{CHRONIC UV EFFECTS}

Although the skin possesses an elaborate AOx system to deal with the oxidative stress, extensive and chronic exposure to UV, associated with abundant ROS/RNS generation, leads to oxidative damage that may result in skin

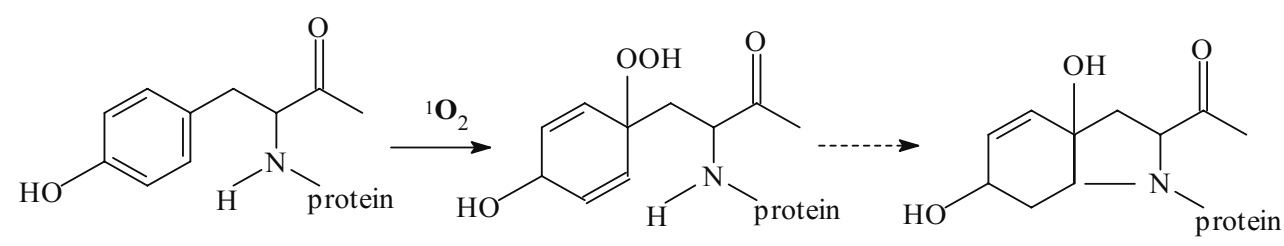

Fig. 7. Singlet oxygen-mediated oxidation of tyrosine (taken from ref. ${ }^{10}$ ). 


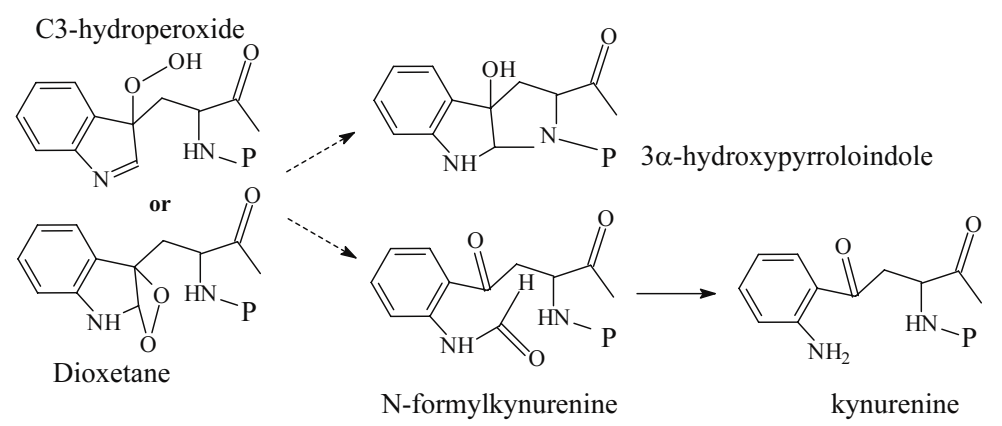

Fig. 8. Products of singlet oxygen-mediated oxidation of tryptophane (taken from ref. ${ }^{10}$.

disorders, inflammation, immunosuppression, premature skin aging (photoaging) and carcinogenesis ${ }^{27,28}$.

UVA is more important in causing skin inflammation in humans than UVB (ref. ${ }^{25}$ ). However UVB participate in the development of the cutaneous inflammatory response as well ${ }^{28}$. The inflammation process includes a cascade of events, which involves infiltration of inflammatory blood leucocytes (macrophages and neutrophils), an increased production of prostaglandins (PGs) as the consequence of increased lipid peroxidation (LPx), a release of tumor necrosis factor-alpha (TNF- $\alpha)$, nuclear factor- $\kappa \mathrm{B}(\mathrm{NF} \kappa \mathrm{B})$, inflammatory cytokines (interleukines; IL-1 $\alpha$, IL-1 $\beta$, IL6 ), which further produce ROS and increase oxidative stress. Inflammation also plays an important role in skin cancer development ${ }^{7}$. Inflammation causes benign human solar keratosis to undergo malignant conversion into SCC probably because the inflammatory cells produce ROS, thus increasing oxidative damage to DNA ( ref. $^{24}$ ). Both UVB and UVA also suppress the human immune system. According to studies, the UVA effect is very intricate and shows a strong genetic dependence. Medium doses modulate immunity; higher doses can protect the immune system from the suppressive effect of UVB, while lower doses (below $840 \mathrm{~mJ} / \mathrm{cm}^{2}$ ) of UVA can enhance the memory of cell development ${ }^{29}$.

Photoaging includes a complex of biologic processes affecting various layers of the skin with the major damage seen in the cognitive tissue of the dermis ${ }^{30}$. This is the result of the chronic sun exposure. The clinical symptoms include dryness, wrinkling, elastosis, telangiectasia, and anomalous pigmentation. Histologically, the dermis is strikingly filled with on amorphous mass of deranged elastic fibers. Collagen fibers are desorganized. Blood vessels are dilated and tortuous. Dermal inflammatory cells are increased. Keratinocytes are irregular with loss of polarity. Melanocytes are abnormal and decreased in number ${ }^{26}$. Although UVB photons are much more energetic than UVA, they are essentially completely absorbed in the epidermis and are mostly responsible for sunburn, suntanning and photocarcinogenesis. Thus UVA is suspected to play a substantial role in photoaging ${ }^{20,26}$. UVAinduced matrix metalloproteinases (MMPs) are capable of degrading the skin collagen framework at the same time as procollagen synthesis is inhibited. MMP-1 cleaves collagen type I, MMP-2 degrades elastin as well as basement membrane compounds including collagen type IV and VII, MMP-3 reveals the broadest substrate specificity for proteins such as collagen type IV, proteoglycans, fibronectin, and laminin ${ }^{16,26,30}$. Levels of procollagen I proteins are decreased in the UV exposed skin. In addition, $\mathrm{NFKB}$ activated by UV radiation, stimulates neutrophil attraction bringing neutrophil collagenase (MMP-8) to the irradiation site to further aggravate matrix degradation. Oxidative stress can also increase elastin mRNA levels in dermal fibroblasts providing a mechanism for the elastolytic changes found in the photoaged dermis. Membrane lipid damage caused by UVA-induced ROS, results in the release of arachidonic acid (AA) and this leads to altered membrane fluidity and activation of secondary cytosolic and nuclear messengers that activate UV-response genes ${ }^{20,26}$. Human skin exposed daily for 1 month to sub-erythemic UVA dose demonstrated epidermal hyperplasia, stratum corneum thickening, Langerhans cell depletion and dermal inflammatory infiltrates with deposition of lysozymes on the elastic fibers ${ }^{31}$. These changes suggest that even casual exposure to sunlight while wearing a UVB-absorbing sunscreen may eventually result in damage to dermal collagen and elastin in ways expected to produce photoaging ${ }^{20}$.

While acute UV radiation induces apoptosis involving p53 and the Fas-Fas ligand pathway, chronic exposure results in disruption of apoptosis regulation leading to abnormal proliferation of keratinocytes containing damaged DNA, accumulation of p53 mutations and loss of Fas-Fas ligand interactions, all of which contribute to carcinogenesis ${ }^{1}$.

\section{UV-INDUCED EXPRESSION OF SKIN ENZYMES}

In addition to macromolecule damage UVA/UVB-generated ROS also affect regulation of gene expression of signalling molecules/cascades (Tab. 2) such as mitogenactivated protein kinases (MAPKs) and interrelated inflammatory cytokines as well as NF-kB and activator protein-1 (AP-1). These may contribute to the induction of heme oxygenase-1 (HO-1) and matrix metalloproteinases (MMPs) in the skin. Increased levels of HO-1 may 
elevate cellular levels of iron that can promote further ROS generation.

\section{Matrix metalloproteinases}

Matrix metalloproteinases (MMPs; EC 3.4.24.X-Y) are a family of zinc-dependent endopeptidases, which are constantly produced by skin cells such as fibroblasts, keratinocytes, macrophages, endothelial cells, mast cells, and eosinophils. They can be induced temporarily in response to exogenous signals including UV radiation ${ }^{2}$. MMPs induction leads to enhanced degradation of the extracellular matrix proteins that favour wrinkle formation. ROS inactivate tissue inhibitors of MMPs and induce the synthesis and activation of matrix-degenerating MMPs. Specific MMPs are induced by UVA trough ${ }^{1} \mathrm{O}_{2}$ and $\mathrm{H}_{2} \mathrm{O}_{2}$ (MMP-1, MMP-2, MMP-3, and MMP-9), whereas UVB generated $\mathrm{OH}$. and LPx induce MMP-1 and MMP-3 and MMP-9 (ref. ${ }^{8,32}$ ). The other pathway of UV-induced expression is due to activation of cell-surface receptors with subsequent activation of MAPKs cascade or via expression of inflammatory cytokines ${ }^{2}$. The increased MMPs synthesis can augment the biological aggressiveness of skin cancer $^{26}$.

\section{Cyclooxygenases}

Cyclooxygenases (COXs; EC 1.14.99.1), prostaglandinendoperoxide synthases, are enzymes that catalyse conversion of AA to PGs. PGs are lipid signalling mediators that play a central role in many normal and pathophysiological processes including inflammation ${ }^{33}$. Of the two known COX enzymes, COX-1 is constitutively expressed in nearly all cells, whereas COX-2 is the inducible form ${ }^{7}$. Both UVA and UVB parts have been shown to induce COX-2 protein expression in $\operatorname{skin}^{34}$. The induction of COX-2 enzyme and an elevated release of AA by phospholipases in the skin result in increased PGs levels. $\mathrm{PGE}_{2}$ resulting from increased COX-2 expression contributes to the uncontrolled proliferation of damaged cells that ultimately form tumors in the skin. COX-2 overexpression and elevated $\mathrm{PGE}_{2}$ levels have been demonstrated in both pre-malignant skin lesions and skin cancers, as well as skin cancer cell lines. In addition, levels of COX-2 activity seem to increase with an invasive potential and seriousness of skin tumors. Normal skin has very low levels of COX-2 and $\mathrm{PGE}_{2}$, pre-malignant human actinic keratosis lesions have increased levels of COX-2 and $\mathrm{PGE}_{2}$, and SCCs have the highest levels of COX-2 and $\mathrm{PGE}_{2}\left(\right.$ ref. $\left.^{7}\right)$. $\mathrm{PGE}_{2}$ interacts with the cytokine cascade including IL-4 and IL-10, which are responsible for the UV-induced systemic immune suppression ${ }^{3}$.

\section{Heme oxygenase}

Heme oxygenase (HO; EC 1.14.99.3) is a redox-regulated enzyme catalyzing the degradation of heme. Two isoforms of $\mathrm{HO}$ have been found in the skin, constitutive HO-2 and inducible HO-1, which respond to a variety of oxidative stressors, including UVA radiation and $\mathrm{H}_{2} \mathrm{O}_{2}$ $\left(\right.$ ref. ${ }^{35}$ ). UVB has been reported to be only weak HO-1 inducer ${ }^{36}$. Both non-enzymatic as well as enzymatic LPx of internal membrane lipids, a decrease in the intracellular
Table 2. Comparison of genes products induced by UVA and UVB radiation.

\begin{tabular}{lcrcr}
\hline & UVA & \multicolumn{1}{c}{ (ref) } & UVB & \multicolumn{1}{c}{ (ref) } \\
\hline MMP-1 & $\uparrow$ & $(17,27,31)$ & $\uparrow$ & $(27,31)$ \\
MMP-2 & $\uparrow$ & $(17,27,31)$ & $*$ & \\
MMP-3 & $\uparrow$ & $(17,27,31)$ & $\uparrow$ & $(27,31)$ \\
MMP-9 & $\uparrow$ & $(17,27)$ & $\uparrow$ & $(33)$ \\
COX-2 & $\uparrow$ & $(17,35)$ & $\uparrow$ & $(35)$ \\
HO-1 & $\uparrow$ & $(17,36)$ & $n$ & $(37)$ \\
iNOS & $*$ & & $\uparrow$ & $(42)$ \\
ODC & $*$ & & $\uparrow$ & $(44,45)$ \\
p53 & $\uparrow$ & $(17,22)$ & $\uparrow$ & $(22)$ \\
Bcl2 & $\uparrow$ & $(17)$ & $\uparrow$ & $(21)$ \\
Bax & $\downarrow$ & $(17)$ & $\downarrow$ & $(21)$ \\
c-jun & $\uparrow$ & $(17)$ & $\uparrow$ & $(7,53)$ \\
c-fos & $\uparrow$ & $(17)$ & $\uparrow$ & $(7,53)$ \\
AP-1 & $\uparrow$ & $(17)$ & $\uparrow$ & $(29)$ \\
NFkB & $\uparrow$ & $(17,52)$ & $\uparrow$ & $(29,51,52)$ \\
TNF- $\alpha$ & $\uparrow$ & $(17)$ & $\uparrow$ & $(29)$ \\
IL-1 & $\uparrow$ & $(17)$ & $\uparrow$ & $(29)$ \\
IL-6 & $\uparrow$ & $(17)$ & $\uparrow$ & $(29)$ \\
\hline
\end{tabular}

$\uparrow$ - induction; $\downarrow$ - downregulation; $\mathrm{n}$ - no effect on this parameter; * information was not found, probably no effect on this parameter.

GSH levels and the integrity of the cytoplasmatic membrane are all important for the UVA-mediated induction of HO-1 (ref. ${ }^{37}$ ). Free heme, released from microsomal heme-containing proteins, that is generated in UVA irradiated cells, also appears to be a critical intermediate that can directly influence both the transcriptional activation and repression of the HO- 1 gene ${ }^{38}$. A high degree of correlation was demonstrated between the amount of released heme and the degree of a subsequent induction of HO-1 transcription following UVA and $\mathrm{H}_{2} \mathrm{O}_{2}$ treatment ${ }^{39}$.

\section{Nitric oxide synthase}

Nitric oxide synthase (NOS; EC 1.14.13.39), which produces NO from L-arginine, has two isoforms: constitutive calcium-dependent (cNOS) and inducible calcium-independent (iNOS) $\left(\right.$ ref. $\left.^{40}\right)$. In UVB-exposed keratinocytes an increased expression of iNOS and a large induction of NO were demonstrated. Higher levels of NOS activity, stimulated by UV radiation, initiate other more complex reactions that include various cell types. The NO liberated following UV radiation plays a significant role in initiating melanogenesis, erythema, and immunosuppression ${ }^{41,42}$.

\section{Ornithine decarboxylase}

Ornithine decarboxylase (ODC; EC 4.1.1.17), the first enzyme in the mammalian polyamine-biosynthesis pathway, plays an important role in the regulation of cell 
proliferation and is a well-established marker for tumor promotion. Acute and chronic UVB exposure leads to induction of epidermal activities and protein expression of ODC (ref. ${ }^{43,44}$ ). UVA irradiation was not found to significantly enhance ODC activity in human skin fibroblasts ${ }^{45}$.

\section{Cytochromes P450}

Cytochromes P450 (CYP) belong to a superfamily of microsomal membrane-bound mono-oxygenases, and are responsible for the metabolic activation of both xenobiotics and endobiotics. They also play an important part in the protective role of the skin. The expression of CYP genes in target cells seems to be an important determinant in the human susceptibility to cancers including skin cancers ${ }^{46,47}$. CYP1A1, widely expressed in extrahepatic tissues, is up-regulated in response to UV. There is evidence that its products participate in defence against oxidative stress. In skin, molecular epidemiological studies have assessed CYP1A1 genotypes in BBC $\left(\right.$ ref $\left.^{48}\right)$. UVA treatment of cultured keratinocytes induced CYP4A11 mRNA expression. Therefore it may participate in the defence mechanism against UVA-induced oxidative damage ${ }^{47}$. It has also been demonstrated that UVB induced both CYP1A1 and CYP1B1 gene expression in human skin. This will probably result in enhanced bioactivation of polycyclic aromatic hydrocarbons and other environmental pollutants to which humans are exposed, which in turn could make the human skin more susceptible to ultraviolet-B-induced skin cancers or allergic and irritant contact dermatitis ${ }^{46,49}$.

\section{PREVENTION OF UV-INDUCED SKIN DAMAGE}

Since the primary function of the skin is to protect the organism against the harmful effect of the environment it has several mechanisms to prevent UV-induced skin alteration. These include cell cycle arrest, apoptosis, where the p53 protein plays an important role, activation of cell survival and proliferation as well as a mechanism to modulate ROS/RNS, including gene expression of skin antioxidant enzymes ${ }^{1,20}$.

Another possibility for cutaneous photoprotection is exogenous application of substances to the skin that support the skin's own protective mechanisms or attenuate the UV penetrating to the skin.

\section{A) ENDOGENOUS MECHANISMS}

\section{Induction of $p 53$ protein}

The $\mathrm{p} 53$ protein, encoded by the tumor suppressor gene $\mathrm{p} 53$, is important in both growth arrest and apoptosis. Upon DNA damage by acute UV radiation, p53 transcription is up-regulated, and p53 protein is activated by phosphorylation at multiple serine residues, including Ser 15, Ser 20, Ser 33, Ser 37, Ser 46, and Ser 392. Various protein kinases such as ATM (ataxia-telangiecta- sia-mutated) and ATR (ATM-related), p38, and MAPKs are involved in the phosphorylation of various $\mathrm{p} 53$ serine residues in response to UV radiation ${ }^{1,20}$. UVA exposure leads to less pronounced and more short-lived p53 activation in comparison to $\mathrm{UVB}^{21}$.

The repair of photo-lesions is the primary response to DNA photodamage in surviving cells. However, if the damage persists into the $\mathrm{S}$ phase of the cell cycle, other repair mechanisms can lead to mutagenesis resulting mainly in a characteristic cytosine to thymine substitution. When such mutations occur in the p53 gene, cells lose their ability to undergo the apoptotic process ${ }^{3,7}$.

\section{Cell cycle arrest}

Cell cycle regulation plays an important role in maintaining the genetic integrity of the cell. A prolonged G1 phase of the cell cycle due to the accumulation of the activated $\mathrm{p} 53$ protein is a characteristic of UVB damaged cells. This allows cells enough time to repair DNA damage before its replication in the $S$ phase or it induces apoptosis in cells with extensive DNA damage. Enhanced expression of cell cycle regulatory proteins such as CDKs and cyclins, and/or decreased or lost expression of cyclin-dependent kinases inhibitors (CDKIs) are causally observed after UV radiation. The $\mathrm{G} 1$ cell cycle arrest is usually accompanied by an increase in CDKI, Cip1/p21 protein, the universal inhibitor of cell cycle progression, in p53-dependent or -independent manner ${ }^{1,20}$.

\section{Activation of apoptosis}

If the DNA damage caused by UV radiation is very severe and cannot be repaired, apoptotic pathways are activated to eliminate damaged cells. Protein p53 as a transactivator of transcription can induce apoptosis by up-regulating the expression of pro-apoptotic genes such as Bax and Fas. Protein p53 mediates cytoplasmic redistribution of death receptor Fas to the cell surface. The Fas-Fas ligand interaction results in the cleavage of procaspase- 8 and release of cytochrome $c$ from mitochondria. The subsequent reaction of cytochrome $c$ with the apoptosis protease-activating factor-1 protein, a key regulator of the mitochondrial apoptotic pathway, results in the recruitment of procaspase-9, activation of the apoptosomal complex, the processing of caspase-3, and finally in apoptosis ${ }^{1,20}$.

Protein p53 also down-regulates the expression of antiapoptotic genes such as Bcl-2 $\left(\right.$ ref. $\left.^{20}\right)$. Findings in mice suggest that apoptosis in response to UV radiation is mediated, at least in part, by the $\mathrm{p} 53 / \mathrm{p} 21 / \mathrm{Bax} / \mathrm{Bcl}-2$ pathway and the dead cells may be replaced by hyperproliferative cells, leading to epidermal hyperplasia. This implies that UV-induced apoptosis and hyperplasia are closely linked, tightly regulated and that deregulation of these pathways may lead to skin cancer development ${ }^{1}$.

\section{Activation of cell survival and proliferation}

At the same time as UV activates cell-cycle check-points and apoptosis, it also stimulates cell surviving mechanisms and induces cell proliferation. UV radiation triggers these 
processes by activating receptors or inhibitors of various growth factors and cytokines. Recent studies have demonstrated that the superfamily of proline/threonine MAPKs, $\mathrm{NF \kappa B}$ and AP-1 play essential roles in mediating the biological effects of UV radiation ${ }^{1,13}$. MAPKs are divided into the extracellular signal-regulated kinases (ERKs), which include p44 (ERK1), and p42 (ERK2), and the stress-activated protein kinases (SAPKs), which are further divided into the c-Jun N-terminal kinases (JNKs; SAPK1), and the p38 kinases (SAPK2). The mechanisms mediating MAPKs activation by UV radiation are multifactorial ${ }^{1,7}$. Proliferating human epidermal keratinocytes respond to UVB in a unique manner in that prior to ERK $1 / 2$ activation, UVB causes a transient but potent down-regulation of the Ras-ERK1/2 signalling cascade ${ }^{1}$.

$\mathrm{NF \kappa B}$ is ubiquitously expressed in an inactive form in most cells, composed of NFKB p50 and Rel A p65 subunits, and bound to an inhibitory protein, Iota kappa $\mathrm{B}$ alpha $(\mathrm{I} \kappa \mathrm{B} \alpha)$. In response to various stimuli, including UVA/UVB light, inflammatory cytokines, DNA damage and variety of mitogens, cytokine is activated and regulates genes involved in inflammation, immunity, cell cycle progression, apoptosis, and oncogenesis ${ }^{7,50,51}$. NF- $\mathrm{KB}$ activation contributes to the production of interleukins or TNF- $\alpha$ and seems to be subject to redox regulation, suggesting thus an important role of antioxidants in its inactivation. The precise mechanism of $\mathrm{NF \kappa B}$ activation by UV radiation is still unclear, but evidence suggests the involvement of ROS, inhibition of the Iota kappa B alpha $(\mathrm{I} \kappa \mathrm{B} \alpha)$ (a negative regulator of $\mathrm{NF} \kappa \mathrm{B})$, and the induction of TNF- $\alpha$ receptor $1 / \mathrm{TNF}-\alpha$ receptor-associated factor- 2 signaling ${ }^{1}$. In particular, the targeted inhibition of $\mathrm{NF \kappa B}$ in the epidermis leads to an increased number of apoptotic keratinocytes and the spontaneous development of SCCs.

AP-1, a member of the transcription factor proteins family, regulates the expression and function of a number of cell cycle regulatory proteins, such as cyclin D1, p53, $\mathrm{p} 21, \mathrm{p} 19$, and $\mathrm{p} 16$. AP-1 is a protein dimer consisting of either heterodimers between fos (c-fos, fos B, Fra-1, Fra-2) and jun (c-jun, Jun B, Jun D) family proteins or homodimer of jun family proteins. UVB strongly induces $c$-jun and c-fos in human primary keratinocytes ${ }^{7}$ as well as in rat skin $^{52}$. It is suggested that $c$-fos expression may play a key role in UVB induced AP-1 activation in human keratinocytes. Proto-oncogene $c$-fos controls cell proliferation and differentiation. It is critical for the regulation of the DNA replication after UV radiation. It eliminates the UV-induced block of the replication and thus appears to play a decisive role in the cellular defence against the genotoxic effect of UV radiation ${ }^{2}$.

\section{Skin antioxidant enzymes}

Superoxide dismutase (SOD; EC 1.15.1.1) belongs to major AOx enzymes that contribute to the homeostasis of oxygen radicals in the epidermis and thus critically participates in the control of senescence and tumor generation. It exists in isozymes, cytosolic CuZnSOD and mitochondrial MnSOD (ref. ${ }^{53}$ ). Several studies have shown a decrease in SOD activity after UVA/UVB exposure. Single and repetitive low doses of UVA exposure to human dermal fibroblasts in vitro resulted in a significant increase in MnSOD on both mRNA and protein levels, and this induction afforded substantial protection against the cytotoxic effect of the UVA insult ${ }^{6}$. UVB irradiation of human keratinocytes was demonstrated to induce a significant increase in SOD activity and protein level. This increase in SOD was attributed to CuZnSOD (ref. ${ }^{53}$ ). UVB irradiation of the epidermal keratinocytes induced release of IL- $1 \alpha$, IL-1 $\beta$, and TNF- $\alpha$ that amplified MnSOD activity in dermal human dermal fibroblasts ${ }^{54}$.

Glutathione peroxidase (GPx; EC 1.11.1.9) is a selenoprotein, that catalyses the conversion of $\mathrm{UV}$-induced $\mathrm{H}_{2} \mathrm{O}_{2}$ into water and molecular oxygen using GSH as a cosubstrate. The activity is not strongly affected by UV and is considered to be the most important AOx defence system in the skin $^{6}$

Catalase (CAT; EC 1.11.1.6) catalyses the conversion of $\mathrm{H}_{2} \mathrm{O}_{2}$ into water and molecular oxygen thus reduces the damaging effects of $\mathrm{H}_{2} \mathrm{O}_{2}$. CAT activity in the skin is strongly reduced after UVA and UVB exposure. This decrease is probably due to irreversible oxidation of the enzyme 6 .

\section{B) EXOGENOUS PHOTOPROTECTION}

Public health authorities recommend a variety ways to limit sun exposure to avoid UV radiation induced injury, such as a use of sunscreens, wearing protective clothing, hats and sunglasses, limiting time spent outdoors during the hours of the highest sun's intensity (10:00 a.m. - 4:00 p.m. or at least 11:00 a.m. - 1:00 p.m.), and use of shade. Of these, the sunscreen use is advised as a primary prevention strategy against sunlight damage ${ }^{55}$. Despite extensive use of sunscreens during last two decades, the incidence of skin cancer has been increasing. The protective activity of sunscreens/their active ingredients is largely based on animal experiments, as it is difficult to carry out long-term studies on humans. Hence lately the role of sunscreens in protecting against skin cancer is intensively discussed.

In a limited number of studies, sunscreen application was demonstrated to decrease the formation of actinic keratoses, which are connected with SCCs. In animal models sunscreens were shown to reduce the incidence of BCCs and SCCs, which are linked to UVB irradiation ${ }^{56}$. However, in several ( 9 of 15 ) epidemiological studies, the use of sunscreens was associated with increased melanoma risk $^{57}$. The efficacy of sunscreens is traditionally assessed using the sun protection factor (SPF). This is defined as the ratio of the least amount of UV energy required to produce minimal erythema on the sunscreen protected skin to the amount of energy required to produce the same erythema on the unprotected $\operatorname{skin}^{58}$. Thus SPF is based solely on a prevention of erythema (sunburn), which is primarily caused by UVB. Thus it cannot be used as an indicator of the damage induced by UVA irradiation. Thus users of the high factor sunscreens may have an artificial 
Table 3. Relationship between the sun protection factor (SPF) and applied sunscreen dose (taken from ref $^{26}$ ).

\begin{tabular}{ccccc}
\hline & \multicolumn{4}{c}{ Dose of sunscreen $\left(\mathrm{mg} / \mathrm{cm}^{2}\right)$} \\
Declared SPF & $\mathbf{0 . 5}$ & $\mathbf{1 . 5}$ & $\mathbf{1 . 5}$ & $\mathbf{2}$ \\
\cline { 2 - 5 } & \multicolumn{4}{c}{ Real-valued SPF } \\
\hline $\mathbf{2}$ & 1.2 & 1.4 & 1.7 & 2.0 \\
$\mathbf{4}$ & 1.4 & 2.0 & 2.8 & 4.0 \\
$\mathbf{8}$ & 1.7 & 2.8 & 4.8 & 8.0 \\
$\mathbf{1 5}$ & 2.0 & 3.9 & 7.6 & 15.0 \\
$\mathbf{3 0}$ & 2.3 & 5.5 & 12.8 & 30.0 \\
$\mathbf{5 0}$ & 2.7 & 7.1 & 18.8 & 50 \\
\hline
\end{tabular}

sense of security that they are similarly protected against UVA which leads to prolonged sunbathing. So the use of high factor sunscreens may paradoxically be associated with the increased skin cancer risk. Several methods for evaluation of the skin UVA-photoprotection afforded by sunscreens exist, however these methods have not been validated and none is universally accepted ${ }^{56}$. The most frequently used in vivo method is the persistent pigment darkening (PPD), in which irradiation of volunteers with a pure UVA light source induces pigmentation ${ }^{59}$.

Moreover the SPF is assessed after phototesting in vivo at an internationally agreed application dose of $2.0 \mathrm{mg}$. $\mathrm{cm}^{-2}$. However, a number of studies have shown that consumers apply much less than this, typically between 0.5 - $1.5 \mathrm{mg} . \mathrm{cm}^{-2}$ (ref. ${ }^{58}$ ). The dose of applied sunscreen is critical for the degree of photoprotection (see Tab. 3) (ref. ${ }^{60}$ ).

Through the $20^{\text {th }}$ century, numerous UV filters having unique characteristic were introduced. These included mainly aminobenzoates, benzophenones, cinnamates, salicylates, camphor derivatives and metal oxides ${ }^{61}$. In European Union (Directive EEC 76/768; 1999; Tab. 4) 28 substances are allowed for sun protective cosmetic. In the Czech Republic (Executive orders No. 174/1998; No. 444/2004; 126/2005; Tab. 4), 23 UV-filters are permitted. In USA (US Food and Drug Administration Sunscreen Monograph Final Rule, 1999; Tab. 4) it is only 16 compounds, which are considered as drugs (camphor derivatives are not allowed) ${ }^{62}$. However, several substances widely used in sunscreens were found to be questinable. For example Parsol 1789, a widely used UVA-absorbing agent present in sunscreens, has been recently found to inadequately protect human keratinocytes from UVA damage ${ }^{63}$. Esters of $p$-aminobenzoic acid were recognized to be phototoxic ${ }^{57}$. Benzophenone-3 was demonstrated to be a photoallergen ${ }^{60}$. Currently used sunscreens do not completely prevent photoaging, photo-immunosuppression or photocarcinogenesis. Inadequate protection of sunscreens may be associated with the lack durability of the application, the lack or inadequacy of UVA filters in sunscreens, the photo-instability of sunscreens filters/ components which result in less protection ${ }^{56}$. Thus there is the need to find efficient UVA photoprotectives and to develop the broad-spectrum sunscreens.
As ROS were established to be responsible for UVAinduced carcinogenesis one strategy for UVA-photoprotection is the support of the endogenous antioxidant system. One alternative to suppressing UV radiation-induced ROS/RNS-mediated injury is the use of compounds naturally present in the skin especially vitamins. However, the effectiveness of vitamin $\mathrm{C}, \mathrm{E}$ and $\mathrm{A}$ (or $\beta$-carotene) in photoprotection is still discussed due to their form of use. While free, but unstable forms are effective, their more stable derivatives (esters) are not powerful in UV protection $^{26,64}$. Thus various natural substances and plant extracts have been studied. Among these, the phenolics have gained prominent importance.

As mentioned above UVB was for a long time considered to be responsible for the UV-induced deleterious effect and for this reason most studies were done on the UVB region. UVB protoprotectivity was shown in several polyphenols and plant extracts such as caffeic and ferulic acid, resveratrol, apigenin, genistein, quercetin ${ }^{5}$, green tea and its components epikatechin and epigalokatechin3-gallate ${ }^{65,66}$, silymarin (a standardized extract from the seeds of Silybum marianum) and its main component silybin $^{67,68}$, Pinus pinaster bark extract, Ginkgo biloba leaves extract $^{65}$, Polypodium leucotomos extract ${ }^{69}$ or Prunella vulgaris extract ${ }^{70}$. Intense investigation of UV influence on the skin revealed that the UVA part is also involved in induction and development of skin cancer. To date only few substances/extracts have been demonstrated to be capable of protecting/suppressing UVA-induced skin cells/ skin injury e.g. carnosic $\operatorname{acid}^{71}$, quercetin ${ }^{72}$, epikatechin ${ }^{74}$, epigallokatechin-3-gallate ${ }^{74,75}$ or $P$. leucotomos extract ${ }^{76}$, silymarin $^{77}$ and $P$. vulgaris extract ${ }^{78}$. Considering the latest knowledge about UV radiation it is necessary to look for new substances possessing both UVA and UVB protection.

\section{CONCLUSION}

It is well known that UV radiation present in sunlight is a potent human carcinogen. It induces various acute and chronic reactions in human and animal skin. Fortunately, cells are equipped with a variety of mechanisms that constantly monitor and repair most of the UV-induced damage. The nucleotide excision repair system prevents the DNA damage from leading to DNA mutations and finally, to skin carcinogenesis. In this process, the p53 gene plays a crucial role by causing cell cycle arrest, giving cell time for DNA repair, or inducing the cell death by apoptosis when the DNA damage cannot be repaired. Other mechanisms such as enzymatic and non-enzymatic antioxidants help cells to eliminate reactive oxygen and nitrogen species, which are extensively generated after UV exposure. Therefore the development of effective strategies to support cellular protection mechanisms appears to be promising in the prevention and therapy of human cutaneous carcinogenesis. 
Table 4. List of permitted UV filters in cosmetic product (Part A).

\begin{tabular}{|c|c|c|c|}
\hline \multirow[t]{2}{*}{ No. } & \multicolumn{3}{|l|}{ SUBSTANCE(S) } \\
\hline & Chemical name (INCI Names/synonyms) & Major trade names & \\
\hline 1 & 4-Aminobenzoic acid (PABA) & & 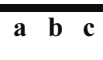 \\
\hline 2 & $\begin{array}{l}\text { N,N,N-Trimethyl-4-(2-oxoborn-3-ylidenmethyl) anilinium methylsulphate } \\
\text { (Camphor benzalkonium methosulfate) }\end{array}$ & Meroxyl SO & a $\mathbf{b}$ \\
\hline 3 & $\begin{array}{l}\text { 3,3,5-Trimethylcyclohexyl-salicylate ((3,3,5-trimethylcyclohexyl) 2- } \\
\text { hydroxybenzoate (Homosalate) }\end{array}$ & Eusolex HMS & a $\mathbf{b} \quad \mathbf{c}$ \\
\hline 4 & 2-Hydroxy-4-methoxybenzophenone (Benzophenone-3; Oxybenzone ) & $\begin{array}{l}\text { Uvinul D50 } \\
\text { Eusolex } 4360 \\
\text { Neo Heliopan B }\end{array}$ & $\mathbf{a} \quad \mathbf{b} \mathbf{c}$ \\
\hline 5 & 2-Cyano-3,3-diphenyl acrylic acid, 2-ethylhexyl ester (Octocrylene) & $\begin{array}{l}\text { Uvinul N539 } \\
\text { Parsol } 340 \\
\text { Eusolex ORC } \\
\text { Neo Heliopan } 303\end{array}$ & $\mathbf{a} \quad \mathbf{b} \mathbf{c}$ \\
\hline 6 & $\begin{array}{l}\text { 2-Phenylbenzimidazole-5-sulphonic acid (Phenylbenzimidazole sulfonic } \\
\text { acid; Ensulizole) and its potassium, sodium and triethanloamine salts }\end{array}$ & $\begin{array}{l}\text { Eusolex } 232 \\
\text { Neo Heliopan HS }\end{array}$ & $\mathbf{a} \quad \mathbf{b} \mathbf{c}$ \\
\hline 7 & Ethoxylated ethyl-4-aminobenzoate (PEG-25 PABA) & Uvinul P25 & a $\mathbf{b}$ \\
\hline 8 & 2-Ethylhexyl salicylate (Octyl salicylate; Octisalate) & $\begin{array}{l}\text { Eusolex OS } \\
\text { Neo Heliopan OS } \\
\text { Solarom OS }\end{array}$ & a $\mathbf{b} \mathbf{c}$ \\
\hline 9 & 2-Ethylhexyl-4-methoxycinnamate (Octyl methoxycinnamate; Octinoxate) & $\begin{array}{l}\text { Parsol MCX } \\
\text { Uvinul MC } 80 \\
\text { Solarom OCM }\end{array}$ & $\begin{array}{lll}a & b & c\end{array}$ \\
\hline 10 & $\begin{array}{l}\text { Isopentyl-4-methoxycinnamate (Isoamyl p-methoxycinnamate; Isopentyl p- } \\
\text { methoxycinnamate) }\end{array}$ & Neo Heliopan E-1000 & a $\mathbf{b}$ \\
\hline 11 & $\begin{array}{l}\text { 1-(4-tert-Butylphenyl)-3-(4-methoxyphenyl) propane-1,3-dione (Butyl } \\
\text { methoxydibenzoyl methane; Avobenzone) }\end{array}$ & $\begin{array}{l}\text { Parsol } 1789 \\
\text { Eusolex } 9820 \\
\text { Neo Heliopan } 357\end{array}$ & $\begin{array}{lll}a & b & c\end{array}$ \\
\hline 12 & $\begin{array}{l}\text { 3,3'-(1,4-Phenylenedimethylene) bis(7,7-dimethyl-2-oxo-bicyclo- } \\
{[2,2,1] \text { hept-1-yl-methanesulphonic acid and its salts (Terephthalylidene }} \\
\text { dicamphor sulfonic acid; Ecamsule ) }\end{array}$ & Meroxyl SX & a b \\
\hline 13 & $\begin{array}{l}\text { 4-Dimethyl-aminobenzoate of ethyl-2-hexyl (Octyl dimethyl PABA; Octyl } \\
\text { dimethyl-4-aminobenzoate; Padimate } O \text { ) }\end{array}$ & $\begin{array}{l}\text { Eusolex } 6007 \\
\text { Uvasorb DMO }\end{array}$ & a $\quad \mathbf{b} \quad \mathbf{c}$ \\
\hline 14 & $\begin{array}{l}\text { 2-Hydroxy-4-methoxybenzophenone-5-sulphonic acid (Benzophenone-4; } \\
\text { Sulisobenzone) and its sodium salt (Benzophenone-5; Sulisobenzone } \\
\text { sodium) }\end{array}$ & Uvinul MS40 & $\begin{array}{lll}a & b & c\end{array}$ \\
\hline 15 & $\begin{array}{l}\text { alpha-(2-Oxoborn-3-ylidene)-toluene-4-sulphonic acid and its salts } \\
\text { (Benzylidene camphor sulfonic acid and salts) }\end{array}$ & Meroxyl SL & a $\mathbf{b}$ \\
\hline 16 & $\begin{array}{l}\text { 3-(4'-Methylbenzylidene-d-1-camphor) (4-methylbenzylidene camphor; } \\
\text { Enzacamene) }\end{array}$ & $\begin{array}{l}\text { Eusolex } 6300 \\
\text { Parsol } 5000 \\
\text { Neo Heliopan MBC }\end{array}$ & a b \\
\hline 17 & 3-Benzylidene camphor & Meroxyl SDS-20 & a $\quad b$ \\
\hline 18 & $\begin{array}{l}\text { (4-(1-methylethyl)pentyl)methyl salicilate (Isopropylbenzyl-salicylate; } \\
\text { Megasol) }\end{array}$ & & a \\
\hline 19 & $\begin{array}{l}\text { 2,4,6-Trianilin-(p-carbo-2'-ethylhexyl-1'-oxy)-1,3,5-triazine (Octyl } \\
\text { triazone; Ethylhexyl Triazone) }\end{array}$ & Uvinul T 150 & a $\mathbf{b}$ \\
\hline
\end{tabular}

${ }^{a}$ in the Czech Republic (Executive orders No. 174/1998, No. 444/2004, 126/2005); ${ }^{\text {b }}$ in European Union (Directive EEC 76/768); ${ }^{\mathrm{c}}$ in USA (Food and Drug Administration Sunscreen Monograph Final Rule). 
Table 4. List of permitted UV filters in cosmetic product (Part B).

\begin{tabular}{|c|c|c|c|}
\hline No. & SUBSTANCE(S) & & \\
\hline & Chemical name (INCI Names/synonyms) & Major trade names & \\
\hline 20 & $\begin{array}{l}\text { Polymer of } \mathrm{N}-\{(2 \text { and } 4)-[(2 \text {-oxoborn-3-ylidene }) \text { methyl }] \text { benzyl }\} \text { acrylamide } \\
\text { (Polyacrylamidomethyl benzilidene camphor) }\end{array}$ & Meroxyl SW & a b \\
\hline 21 & $\begin{array}{l}\text { (1,3,5)-Triazine-2.4-bis((4-(2-ethylhexyloxy)-2-hydroxy)phenyl)-6-(4- } \\
\text { methoxyphenyl) (Anisotriazine) }\end{array}$ & Tinosorb S & b \\
\hline 22 & $\begin{array}{l}\text { 2,2'-Methylene-bis-6-(benzotriazol-2yl)-4-(tetramethyl-butyl)-1,1,3,3,- } \\
\text { phenol (Methylene bisbenzotriazolyl tetramethyl butyl phenol) }\end{array}$ & Tinosorb M & b \\
\hline 23 & $\begin{array}{l}\text { Benzoic acid, 4,4-((6- }(((1,1- \\
\text { dimethylethyl)amino)carbonyl)phenyl)amino)1,3,5-triazine- } \\
\text { 2,4diyl)diimino)bis-,bis-(2-ethylhexyl)ester) (Dioctyl butamido triazone; } \\
\text { Diethylhexyl Butamido Triazone })\end{array}$ & Uvasorb HEB & b \\
\hline 24 & $\begin{array}{l}\text { Monosodium salt of 2,2'-bis-(1,4phenylene)1H-benzimidazole-4,6- } \\
\text { disulphonic acid) (Bisymidazylate) }\end{array}$ & & b \\
\hline 25 & $\begin{array}{l}\text { Phenol, 2-(2H-benzotriazol-2-yl)-4-methyl-6-(2-methyl-3-(1,3,3,3- } \\
\text { tetramethyl-1-(trimethylsilyl)oxy)disiloxanyl)propyl) or 2-(2 H- } \\
\text { benzotriazolyl)6\{[3(1,1,1,3,5,5, 5-heptamethyltrisiloxan-3-yl]2- } \\
\text { methylpropyl }\} 4-m e t h y l f e n o l \text { (Drometrizole trisiloxane) }\end{array}$ & $\begin{array}{l}\text { Meroxyl XL } \\
\text { Sialtrizole }\end{array}$ & b \\
\hline 26 & Dimethicodiethylbenzal malonate (Polysilicone-15) & Parsol SLX & a $\mathbf{b}$ \\
\hline 27 & $\begin{array}{l}\text { 2-(4-(Diethylamino)-2-hydroxybenzoyl-hexylbenzoate (Diethylamino } \\
\text { hydroxybenzoyl hexyl benzoate) }\end{array}$ & Uvinul A Plus & a $\mathbf{b}$ \\
\hline 28 & Dioxybenzone (Benzophenone-8) & Spectra Sorb UV-24 & \\
\hline 29 & Trolamine salicylate & $\begin{array}{l}\text { Neo Heliopan TES } \\
\text { Sunarom TS }\end{array}$ & \\
\hline 30 & Menthyl anthranilate (Meradimate) & $\begin{array}{l}\text { Neo Heliopan MA } \\
\text { Solarom MA }\end{array}$ & \\
\hline 31 & 2-Ethoxyethyl p-methoxycinnamate (Cinoxate) & & \\
\hline 32 & Titanium dioxie; micronized & Hombitec L7 & a $\mathbf{b} \mathbf{c}$ \\
\hline 33 & Zinc oxide; micronized & Zinkoxid & b $\mathbf{c}$ \\
\hline
\end{tabular}

a in the Czech Republic (Executive orders No. 174/1998, No. 444/2004, 126/2005); ${ }^{b}$ in European Union (Directive EEC 76/768); ' in USA (Food and Drug Administration Sunscreen Monograph Final Rule).

\section{ACKNOWLEDGEMENT}

This work was supported by the Ministry of Education of the Czech Republic (Research concept MSM 6198959216).

\section{REFERENCES}

1. Melnikova VO, Ananthaswamy NH. (2005) Cellular and molecular events leading to the development of skin cancer. Mutat Res 571, 91-106.

2. Hussein MR. (2005) Ultraviolet radiation and skin cancer: molecular mechanisms. J Cutan Pathol 32, 191-205.

3. Clydesdale GJ, Dandie GW, Muller HK. (2001) Ultraviolet light induced injury: Immunological and inflammatory effests. Immunol Cell Biol 79, 547-68.

4. Duthie MS, Kimber I, Norval M. (1999) The effects of ultraviolet radiation on the human immune system. Br J Dermatol 140, 995-1009.
5. De Gruijl FR, Van der Leun JC. (2000) Environment and health: 3. Ozone depletion and ultraviolet radiation. CMAJ 163, 851-5.

6. Afaq F, Mukhtar H. (2001) Effects of solar radiation on cutaneous detoxification pathways. J Photochem Photobiol B 63, 61-9.

7. Afaq F, Mukhtar H. (2002) Photochemoprevention by botanical antioxidants. Skin Pharmacol Appl Skin Physiol 15, 297-306.

8. Trautinger F. (2001) Mechanisms of photodamage of the skin and its functional consequences for skin agening. Clin Exp Dermatol 26, 573-7.

9. De Gruijl RR. (2002) Photocarcinogenesis: UVA vs. UVB radiation. Skin Pharmacol Appl Skin Physiol 15, 316-20.

10. Pattison DI, Davies MJ. (2006) Actions of ultraviolet light on cellular structures. EXS 96, 131-57.

11. Petit Frere C, Clingen PH, Arlett CF, Green MH. (1996) Inhibition of RNA and DNA synthesis in UV-irradiated normal human fibroblasts is correlated with pyrimidine (6-4) pyrimidone photoproduct formation. Mutat Res 354, 87-94.

12. Van der Leun JC. (2004) The ozone layer. Photodermatol Photoimmunol Photomed 20, 159-62.

13. Heck DE, Gerecke DR, Vetrano AM, Laskin JD. (2004) Solar 
ultraviolet radiation as a trigger of cell signal transduction. Toxicol Appl Pharmacol 195, 288-97.

14. Godar DE. (2005) UV doses worldwide. Photochem Photobiol 81, $736-49$.

15. Kanofsky JR, Sima P. (1991) Singlet oxygen production from the reactions of ozone with biological molecules. J Biol Chem 266 9039-42.

16. Thiele J, Elsner P. Oxidants and antioxidants in cutaneous biology. Basel: Karger, 2001.

17. Kulms D, Schwarz T. (2000) Molecular mechanisms of UV-induced apoptosis. Photodermatol Photoimmunol Photomed 16 , 195-201.

18. Norval M, El-Ghorr AA. (2002) Studies to determine the immunomodulating effects of cis-urocanic acid. Methods 28, 63-70.

19. Ischihashi M, Ueda M, Budiyanto A, Bito T, Oka M, Fukunaga M, Tsuru K, Horikawa T. (2003) UV-induced skin damage. Toxicology 189, 21-39.

20. Matsumura Y, Ananthaswamy HN. (2004) Toxic effects of ultraviolet radiation on the skin. Toxicol Appl Pharmacol 195, 298-308.

21. Kappes UP, Luo D, Potter M, Schulmeister K, Runger. (2006) Short- and long-wave UV light (UVB and UVA) induce similar mutations in human skin cells. J Invest Dermatol 126, 667-75.

22. Sander CS, Chang H, Hamm F, Elsner P, Thiele JJ. (2004) Role of oxidative stress and the antioxidant network in cutaneous carcinogenesis. Int J Dermatol 43, 326-35.

23. Inal ME, Kahramant A, Kökent T. (2001) Beneficial effects of quercetin on oxidative stress induced by ultraviolet $A$. Clin Exp Dermatol 26, 536-9.

24. Halliday GM. (2005) Inflammation, gene mutation and photoimmunosuppression in response to UVR-induced oxidative damage contribute to photocarcinogenesis. Mutat Res 571, 107-20.

25. Nishigori C, Hattori Y, Toyokuni S. (2004) Role of reactive oxygen species in skin carcinogenesis. Antioxid Redox Signal 6, 561-70.

26. Pinnell SR. (2003) Cutaneous photodamage, oxidative stress, and topical antioxidant protection. J Am Acad Dermatol 48, 1-19.

27. Katiyar SK, Elmets CA. (2001) Green tea antioxidants and skin photoprotection. Int J Oncol 18, 1307-13.

28. Grandjean-Laquerriere A, Le Naour R, Gangloff SC, Guenounou M. (2003) Differential regulation of TNF-alpha, IL-6 and IL-10 in UVB-irradiated human keratinocytes via cyclic AMP/protein kinase A pathway. Cytokine 23, 138-49.

29. Halliday G, Bryne SN, Kuchel JM, Poon TS, Barnetson RS. (2004) The suppression of immunity by ultraviolet radiation: UVA, nitric oxide and DNA damage. Photochem Photobiol Sci 3, 736-40.

30. Scharffetter-Kochanek K, Brenneisen P, Wenk J, Herrmann G, Ma W, Kuhr L, Meewes C, Wlaschek M. (2000) Photoaging of the skin: from phenotype to mechanisms. Exp Geront 35, 307-16

31. Lavker RM, Gerberick GF, Veres D, Irwin CJ, Kaidbey KH. (1995) Cumulative effects from repeated exposures to suberythemal doses of UVB and UVA in human skin. J Am Acad Dermatol 32, 5362.

32. Onoue S, Kobayashi T, Takemoto Y, Sasaki I, Shinkai H. (2003) Induction of matrix metalloproteinase-9 secretion from human keratinocytes in culture by ultraviolet B irradiation. J Dermatol Sci 33, 105-11.

33. Lee JL, Mukhtar H, Bickers DR, Kopelovich L, Athar M. (2003) Cyclooxygenases in the skin: pharmacological and toxicological implications. Toxicol Appl Pharmacol 192, 294-306.

34. Mahns A, Wolber R, Stab F, Klotz LO, Sies H. (2004) Contribution of UVB and UVA to UV-dependent stimulation of cyclooxygenase2 expression in artificial epidermis. Photochem Photobiol Sci 3 , 257-62.

35. Allanson M, Reeve VE. (2005) Ultraviolet A (320-400 nm) modulation of ultraviolet B (290-320 nm)-induced immune suppression is mediated by carbon monoxide. J Invest Dermatol 124, 644-50.

36. Obermuller-Jevic UC, Schlegel B, Flaccus A, Biesalski HK. (2001) The effect of beta-carotene on the expression of interleukin- 6 and heme oxygenase-1 in UV-irradiated human skin fibroblasts in vitro. FEBS Lett 509, 186-90.

37. Basu-Modak S, Luscher P, Tyrrell RM. (1996) Lipid metabolite involvement in the activation of the human heme oxygenase-1 gene. Free Radic Biol Med 20, 887-97.
38. Tyrrell RM. (2004) Solar ultraviolet A radiation: an oxidizing skin carcinogen that activates heme oxygenase-1. Antioxid Redox Signal $6,835-40$.

39. Kvam E, Noel A, Basu-Modak S, Tyrrell RM. (1999) Cyclooxygenase dependent release of heme from microsomal hemeproteins correlates with induction of heme oxygenase 1 transcription in human fibroblasts. Free Radic Biol Med 26, 511-7.

40. Paunel AN, Dejam A, Thelen S, Kirsch M, Horstjann M, Gharini P, Murtz M, Kelm M, Groot H, Kolb.Bachofen V, Suschek CV. (2005) Enzyme-independent nitric oxide formation during UVA challenge of human skin: characterization, molecular sources, and mechanisms. Free Radic Biol Med 38, 606-15.

41. Chang HR, Tsao DA, Wang SR, Yu HS. (2003) Expression of nitric oxide synthases in keratinocytes after UVB irradiation. Arch Dermatol Res 295, 293-6.

42. Cals-Grierson MM, Ormerod AD. (2004) Nitric oxide function in the skin. Nitric Oxide 10, 179-93.

43. Hillebrand GG, Wilsow MS, Benzinger MJ, Heitmeyer DA, Bissett DL. (1990) Acute and chronic ultraviolet radiation induction of epidermal ornithine decarboxylase activity in hairless mice. Cancer Res 50, 1580-4.

44. Arnold WP, Pennings BJ, van de Kerkhof PC. (1992) The induction of ornithine decarboxylase in human epidermis is independent of lipoxygenase and cyclo-oxygenase pathways. J Dermatol 19, 461-4.

45. Francz PI, Conrad J, Biesalski HK. (1998) Modulation of UVAinduced lipid peroxidation and suppression of UVB-induced ornithine decarboxylase response by all-trans-retinoic acid in human skin fibroblasts in vitro. Biol Chem 379, 1263-9.

46. Katiyar SK, Matsui MS, Mukhtar H. (2000) Ultraviolet-B exposure of human skin induces cytochromes P450 1A1 and 1B1. J Invest Dermatol 114, 328-33.

47. Gonzalez MC, Marteau C, Franchi J, Migliore-Samour D. (2001) Cytochrome P450 4A11 expression in human keratinocytes: effects of ultraviolet irradiation. Br J Dermatol 145, 749-57.

48. Lear JT, Smith AG, Strange R, Fryer AA. (2000) Detoxifying enzyme genotypes and susceptibility to cutaneous malignancy. Br J Dermatol 142, 8-15.

49. Villard PH, Sampol E, Elkaim JL, Puyoou F, Casanova D, Seree E, Durand A, Lacarelle B. (2002) Increase of CYP1B1 transcription in human keratinocytes and $\mathrm{HaCaT}$ cells after UV-B exposure. Toxicol Appl Pharmacol 178,137-43.

50. Vile GF, Tanew-Ilitschew A, Tyrrell RM. (1995) Activation of NFkappa $B$ in human skin fibroblasts by the oxidative stress generated by UVA radiation. Photochem Photobiol 62, 463-8.

51. Loercher A, Lee TL, Ricker JL, Howard A, Geoghegen J, Chen Z, Sunwoo JB, Sitcheran R, Chuang EY, Mitchell JB, Baldwin AS Jr, Van Waes C. (2004) Nuclear factor-kappaB is an important modulator of the altered gene expression profile and malignant phenotype in squamous cell carcinoma. Cancer Res 64, 6511-23.

52. Gillardon F, Eschenfelder C, Uhlmann E, Hartschuh W, Zimmermann M. (1994) Differential regulation of c-fos, fosB, cjun, junB, bcl-2 and bax expression in rat skin following single or chronic ultraviolet irradiation and in vivo modulation by antisense oligodeoxynucleotide superfusion. Oncogene 9, 3219-25.

53. Sasaki H, Akamatsu H, Horio T. (1997) Effects of a single exposure to UVB radiation on the activities and protein levels of copper-zinc and manganese superoxide dismutase in cultured human keratinocytes. Photochem Photobiol 65, 707-13.

54. Naderi-Hachtroudi L, Peters T, Brenneisen P, Meewes C, Hommel C, Razi-Wolf Z, Schneider LA, Schuller J, Wlaschek M, Scharffetter-Kochanek K. (2002) Induction of manganese superoxide dismutase in human dermal fibroblasts: a UV-B-mediated paracrine mechanism with the release of epidermal interleukin 1 alpha, interleukin 1 beta, and tumor necrosis factor alpha. Arch Dermatol 138, 1473-9.

55. Harris RB, Alberts DS. (2004) Strategies for skin cancer prevention. Int J Dermatol 43, 243-51.

56. Haywood R, Wardman P, Sanders R, Linge C. (2003) Sunscreens inadequately protect against ultraviolet-A-induced free radicals in skin: implications for skin aging and melanoma? J Invest Dermatol $121,862-8$ 
57. Wolf R, Wolf D, Morganti P, Ruocco V. (2001) Sunscreens. Clin Dermatol 19, 452-9.

58. Diffey B. (2001) Sunscreen isn't enough. J Photochem Photobiol B $64,105-8$.

59. Herzog B, Mongiat S, Quass K, Deshayes C. (2004) Prediction of sun protection factors and UVA parameters of sunscreens by using a calibrated step film model. J Pharm Sci 93, 1780-95.

60. Rosen CF. (2003) Topical and systemic photoprotection. Dermatol Ther $16,8-15$

61. Nash JF. (2006) Human safety and efficacy of ultraviolet filters and sunscreen products. Dermatol Clin 24, 35-51.

62. Ettler K. Fotoprotekce kůže. Ochrana kủže před účinky ultrafialového záření. Praha: TRITON s.r.o., 2004

63. Armeni T, Damiani E, Battino M, Greci L, Principato G. (2004) Lack of in vitro protection by a common sunscreen ingredient on UVA-induced cytotoxicity in keratinocytes. Toxicology 203, 165-78.

64. F'guyer S, Afaq F, Mukhtar H. (2003) Photochemoprevention of skin cancer by botanical agents. Photodermatol Photoimmunol Photomed 19, 56-72.

65. Svobodova A, Psotova J, Walterova D. (2003) Natural phenolics in the prevention of UV-induced skin damage. A review. Biomed Pap Med Fac Univ Palacky Olomouc Czech Repub 147, 137-45.

66. Hsu S. (2005) Green tea and the skin. J Am Acad Dermatol 52, 1049-59.

67. Katiyar SK. (2005) Silymarin and skin cancer prevention: anti-inflammatory, antioxidant and immunomodulatory effects (Review). Int J Oncol 26, 169-76.

68. Singh RP, Agarwal R. (2005) Mechanism and preclinical efficacy of silibinin in preventing skin cancer. Eur J Cancer 41, 1969-79.

69. Gonzales S, Pathak MA. (1996) Inhibition of ultraviolet-induced formation of reactive oxygen species, lipid peroxidation, erythema and skin photosensitization by polypodium leucotomos. Photodermatol Photoimmunol Photomed 12, 45-56.
70. Bonte F, Meybeck A, Dumas M.(LVMH Recherche):WO 92/21322 (10.12.1992).

71. Offord EA, Gautier JC, Avanti O, Scaletta C, Runge F, Krämer K, Applegate LA. (2002) Photoprotective potential of lycopene, b-carotene, vitamin E, vitamin C, and Carnosic acid in UVA-irradiated human skin fibroblast. Free Radic Biol Med 32, 1293-1303.

72. Erden Inal M, Kahramant A, Kökent T. (2001) Beneficial effects of quercetin on oxidative stress induced by ultraviolet A. Clin Exp Dermatol 26, 536-9.

73. Basu-Modak S, Gordon MJ, Dobson LH, Spencer JP, Rice-Evans C, Tyrrell RM. (2003) Epicatechin and its methylated metabolite attenuata UVA-induced oxidative damage to human skin fibroblasts. Free Radic Biol Med 35, 910-21.

74. Tobi SE, Gilbert M, Paul N, McMillan TJ. (2002) The green tea polyphenol, epigallocatechin-3-gallate, protects against the oxidative cellular and genotoxic damage of UVA radiation. Int J Cancer $102,439-44$

75. Huang CC, Fang JY, Wu WB, Chiang HS, Wei YJ, Hung CF. (2005) Protective effects of (-)-epicatechin-3-gallate on UVA-induced damage in HaCaT keratinocytes. Arch Dermatol Res 296, 473-81.

76. Philips N, Smith J, Keller T, Gonzales S. (2003) Predominant effects of Polypodium leucotomos on membrane integrity, lipid peroxidation, and expression of elastin and matrixmetalloproteinase-1 in ultraviolet radiation exposed fibroblasts, and keratinocytes. J Dermatol Sci 32, 1-9.

77. Svobodová A, Zdařilová A, Mališková J, Mikulková H, Walterová D, Psotová J. (2006) Attenuation of UVA-induced oxidative damage to human keratinocytes by silymarin. Free Radic Biol Med (submitted).

78. Psotová J, Svobodová A, Kolářová H, Walterová D. (2006) Photoprotective properties of Prunella vulgaris and rosmarinic acid on human keratinocytes. J Photochem Photobiol B (accepted). 